\title{
Post-logging regeneration in a mature tropical rainforest stand, Gajabuih, Ulu Gadut, West Sumatra
}

\author{
Elias Thiam ${ }^{1}$, Reki Kardiman ${ }^{2}$, Tsuyoshi Yoneda ${ }^{1 *}$ and Erizal Mukhtar ${ }^{2}$ \\ 'Faculty of Agriculture, Kagoshima University, Kagoshima 890-0065, Japan \\ ${ }^{2}$ Faculty of Mathematics and Natural Sciences, Andalas University, Indonesia \\ *Corresponding author: yoneda@agri.kagoshima-u.ac.jp
}

\begin{abstract}
We examined regeneration processes within a permanent 0.9 ha tropical rainforest plot located in the West Sumatran Ulu Gadut region at about $630 \mathrm{~m}$ altitude. Our study site, the Gajabuih plot (GJB), was heavily logged in 1997. This induced conspicuous decreases in species number and diversity. Logging affected major climax species, few of which survived as standing trees. Species ordination analysis revealed a shift from a mature forest similar to that of a little-disturbed plot in the same region (PIN) to a young regenerating stand dominated by vigorous pioneer secondary forest species, such as Villebrunea rubescens (shade tolerant, random habitat preferences) and Mallotus paniculatus (widely dispersing species). Sprouter species made up $79 \%$ of calculated importance values in the regenerating stand. Single-stemmed trees (77\% of total basal area) dominated the stand irrespective of species groups (survived or newcomer). Single-stemmed and multi-stemmed trees tended to be located on low slopes and ridge sites, respectively. The life strategy spectrum of the trees suggests that increases in the incidence of sprouting were promoted by heavy disturbance and variation in topographical structure. Sprouting abilities were negatively correlated with potential growth rates, as were shoot mortalities after storm damage. However, sprouting ability was positively correlated with the mechanical strength of trees (stem hardness). Using this information, we explored regeneration capacity by sprouting of tropical forests across environmental gradients of resources and disturbance.
\end{abstract}

Key words: life strategies, logging, regeneration, sprouting ability, succession

\section{INTRODUCTION}

Indonesia occupies only $1.3 \%$ of global land surface but its tropical forests contain $>10 \%$ of the planet's plant species (Hamilton 1997). Logging activities since the Asian financial crisis in 1997 have caused a conspicuous reduction in and fragmentation of forested lands (Kobayashi 2004). There have been continuous changes in the vegetation structures of West Sumatra (Laumonier et al. 2010, Otsuka 2009, Thiam and Yoneda 2012, Yoneda et al. 2006). Comparative studies in this area have improved understanding of altitudinal and horizontal dynamics of the forests (Vitousek et al. 1997, Nishimura et al. 2006, Yoneda. et al. 1994). However, the regeneration process is greatly affected by local conditions, and the available data are insufficient for analysis of small-scale regeneration processes over protracted time periods (Yoneda et al. 1999, Thiam and Yoneda 2012).

Some disturbances in tropical forests promote habitat sharing between shade-intolerant and fast-growing species (Yamamoto 1992, Everham and Brokaw 1996,
Whitmore 1998). Gaps created by disturbance allow the establishment of seedlings from species in the local mature community. New species also appear in disturbed stands, although a portion of the pre-disturbance community still exists. Thus, conspicuous changes in species composition occur following disturbance. Logging in a mature forest is a form of disturbance that affects indigenous species that are dependent on the presence of mature habitats (Kimmins 2004). In strongly disturbed areas subjected to frequent perturbation, there is a dramatic decrease in diversity because only species with high regeneration capabilities are able to persist (Connell 1978). Such species have a range of different regeneration traits (sprouting or seeding) that are expressed as a function of local environmental conditions (Chong et al. 2007). Without disturbance, trees typically allocate high proportions of their carbohydrate budgets to the formation of single long-lived trunks ( $\mathrm{Ng} \mathrm{1999,}$ Tredici 2001). However, some changes in environmental conditions induce increased incidence of multi-stemmed trees (Tredici 2001); the ecological significance of this strategy has been explored in only a few mesic forests 
and has been largely neglected in the management of woodland species (Bond and Midgley 2001). Analyses of recovery processes in over-logged mature forests (with particular regard to sprouting and non-sprouting species) could contribute significantly to improved understanding of ecological processes in tree stands.

We explored the temporal dynamics in vertical and horizontal dimensions, changes in species compositions and sprouting abilities of surviving trees 14 years after clear-cutting of a mature forest in the Gajabuih plot (GJB). We focused on the dynamics of stand structure with due regard for species origin in the disturbed plot and regeneration traits. We discuss the regeneration processes of this tropical rainforest in terms of recovery rates, life strategies, succession, and the incidence of sprouting. Our findings would be useful for developing plans for forest resource production that would reduce the destructive impacts of logging (Kobayashi 2004). Rehabilitation, protection and conservation of areas of high biological interest are pressing issues for sustainable management.

\section{MATERIALS AND METHODS}

Study site

Our study site was located in a typical tropical rainforest in West Sumatra where the average annual rainfall is $>6000 \mathrm{~mm}$ (Fig. 1). Developed forests occurring in the headwaters of the Sungai Gadut Gadang River contribute considerably to flood protection of Padang City. Studies in permanent plots of Ulu Gadut since 1980 have revealed high species diversity that includes many endemics, such as Raflessia gadutensis (Hotta et al. 1984).

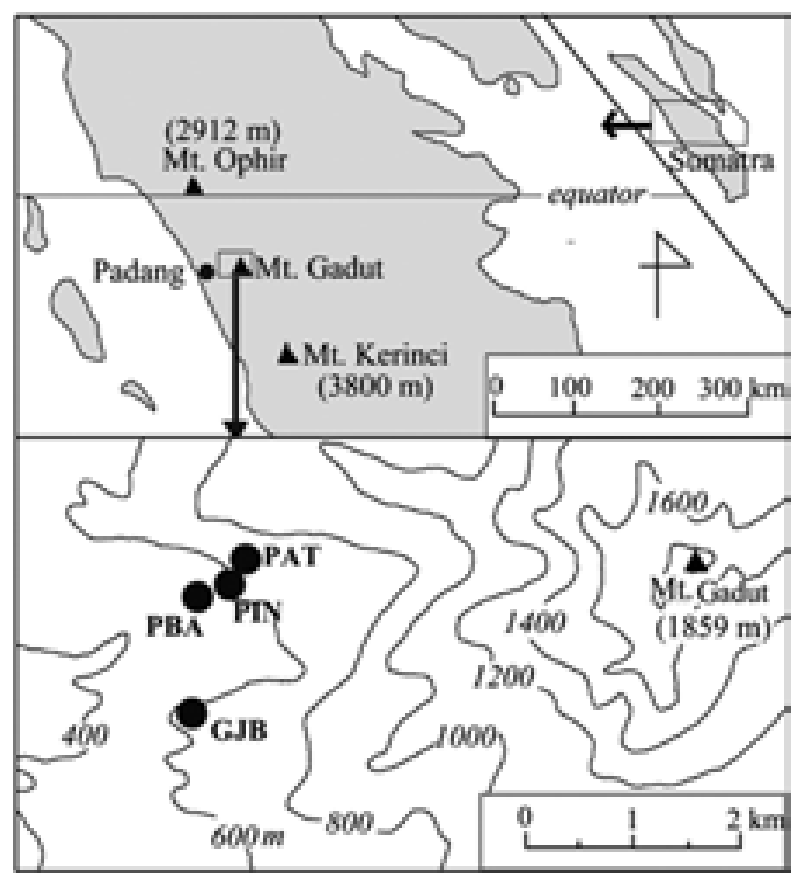

Fig. 1. Locations of research sites in West Sumatra. Padang is the capital city of the province of West Sumatra. Symbols of GJB, PIN, PBA and PAT were the main research plot, Gajabuih, and three cited plots in this paper, respectively.

Gajabuih is a 0.9-ha permanent plot located in the Ulu Gadut area of West Sumatra at about $630 \mathrm{~m}$ altitude $\left(0^{\circ} 55^{\prime} 47.151^{\prime \prime} \mathrm{S}, 100^{\circ} 30^{\prime} 7.540^{\prime \prime} \mathrm{E}\right)$. The original plot was established in 1980. The vegetation includes a mature hill dipterocarp forest characterized by the dominance of Shorea maxwelliana, Lithocarpus spp., Litsea spp., Eugenia spp., Canarium spp., and emergent trees of Swintonia shwenchii and Deplanchea bancana (Hotta 1989). After repeated disturbance, including the most

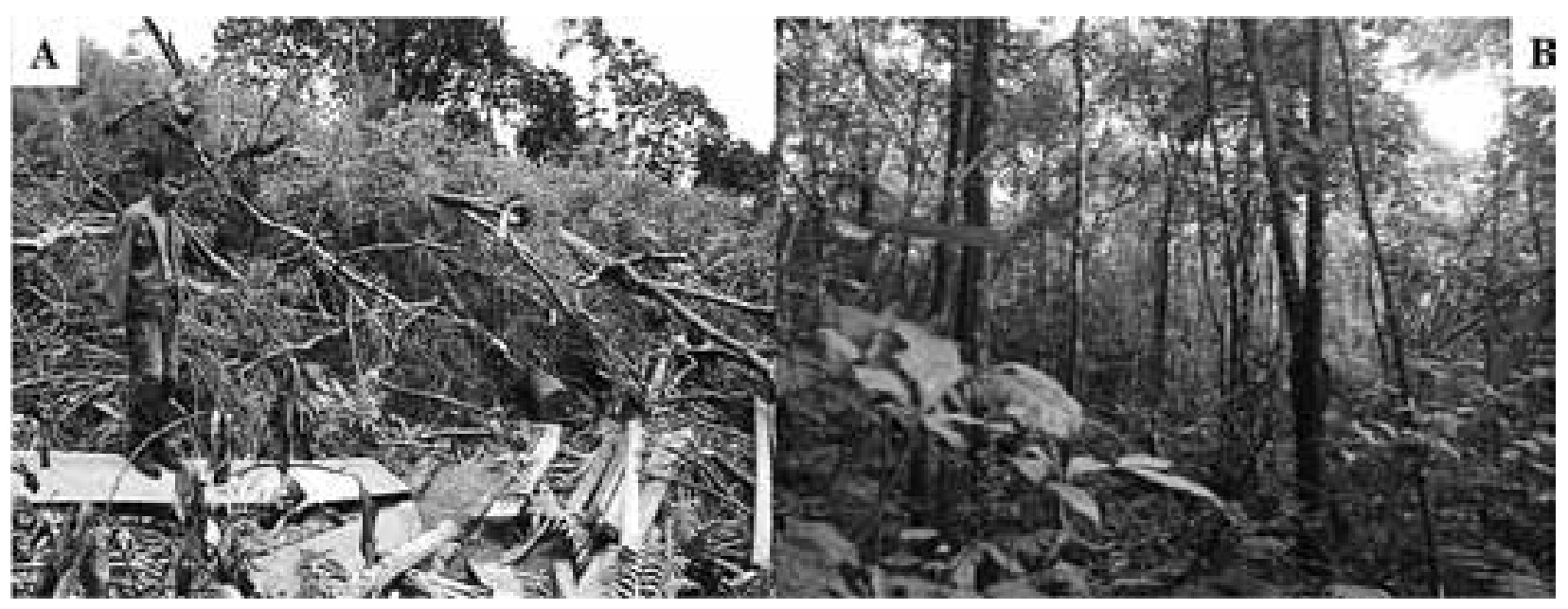

Photograph. A) The Gajabuih plot in July 2000: continuous logging of trees at the time. B) Present condition of the Gajabuih plot in October 2011: a young regenerating stand after logging. 
severe logging in 1997, the vegetation structure shifted from that of an old growth forest to a young regenerating stand where small-scale disturbance by local people is still continuing (Photo A and B). On 28 July 2010, a storm struck with a maximum wind velocity of 25 knots, i.e., $46.3 \mathrm{~km} \mathrm{~h}^{-1}$ (the nearest meteorological station at Tabing in Padang City), which increased tree mortality.

We used data-base of tree census at the original GJB forest before logging and two neighboring research plots in this Ulu Gadut region for comparative analysis (Yoneda et al. 1999). They were Pinang Pinang Bawah Plot (PBA, a 0.09 ha plot located at about $500 \mathrm{~m}$ in altitude) and Pinang Pinang Plot (PIN) (Fig. 1, a 1.0 ha plot at about $600 \mathrm{~m}$ in altitude). PBA was a secondary forest stand after clear cutting in 1980, and tree census was conducted during 12 years starting from 4 years after cutting (19841996). Secondary forest species mostly germinated after the last logging and dominated at this plot. They were Vernonia arborea, Mallotus moluccanus, Urticaceae sp., Mal. paniculatus and Dendrocnide stimulans. PIN was a 1-ha mature forest stand characterized by dominance of Swintonia schwenchii in an emergent layer and high abundance in the canopy layer without prominent dominant species (Yoneda et al. 1990). Long-term tree census has been conducted since 1981, and data-base during the period 1981-1996 was applied to this paper. Data-base at the original GJB forest before logging was obtained from the period 1980-1996.

\section{Tree census}

We could re-establish all 100 subplots of GJB in 2010 using marker poles of the plot before logging. The subplots are small quadrats with area ca. $100 \mathrm{~m}^{2}$ (Fig. 4, topographical map from Ogino et al. 1984). They are arranged from North-East to South, except for 10 quadrats in the western slope directed perpendicularly. We measured the diameter at breast height (DBH) of all stems $\geqq 5 \mathrm{~cm} \mathrm{DBH}$ in September 2010 and September 2011. Single-stemmed and multi-stemmed individuals were noted. We recorded parameters including stem hardness and position of each individual. The general features of the GJB before and after logging are given in Table 1. Stem hardness of each tree was measured thrice using the nail method (Yoneda 1997, Yoneda et al. 2006) and the arithmetic mean of these three measurements was used to represent the hardness of an individual tree.

Specimens were collected during our fieldwork and brought to the Herbarium Bogoriense in Bogor (West Java, Indonesia), where they were identified. They were filed at Andalas and Kagoshima universities.

Data-base at PBA, the original GJB and PIN supplied us data of trees $\geqq 5 \mathrm{~cm} \mathrm{DBH}$ at the the former one secondary forest and $\geqq 8 \mathrm{~cm} \mathrm{DBH}$ at the latter two mature forests during each observation period.

\section{Clipping experiment with Villebrunea rubescens (Urticaceae)}

We examined the responses of a dominant species (Villebrunea rubescens) to stem clipping at different stump heights $(10,30,60$, and $100 \mathrm{~cm})$ with 10 individuals per category, except the first, which included 9 individuals. Parameters recorded before cutting were $\mathrm{DBH}$, stump diameter and stump height. Tree size was not significantly different among the four stump heights; the average value was $5.4 \pm 1.2 \mathrm{~cm}$ in DBH $(P=0.247)$. Monthly monitoring of sprout number and lengths of all sprouted shoots was conducted for each individual over 6 months starting in October, 2011.

\section{Classification of species and trees}

Tree species were classified into three groups (survived, newcomer and disappeared). We defined survived species as those recorded before and after logging. They comprised trees that were newly regenerated from stumps or seeds and non-logged trees. Newcomer was defined to be species that were not present in 1996 or were not recorded in the data-base as target trees $\geqq 8 \mathrm{~cm}$ DBH. Disappeared species were defined as those recorded only before logging.

We distinguished between sprouting ("sprouters") and non-sprouting species ("seeders"), the former having

Table 1. General features of the Gajabuih stand before and after logging in 1997. A symbol of Dmax is the maximum DBH at each census *: DBH $\geqq 8 \mathrm{~cm} ; * *$ DBH $\geqq 5 \mathrm{~cm}$

\begin{tabular}{|c|c|c|c|c|c|c|}
\hline Time calendar year & Species number (plot $\left.{ }^{-1}\right)$ & Basal area $\left(\mathrm{m}^{2} \mathrm{ha}^{-1}\right)$ & Tree density $\left(\mathrm{ha}^{-1}\right)$ & Shoot density $\left(\mathrm{ha}^{-1}\right)$ & $\operatorname{Dmax}(\mathrm{cm})$ & Shannon index $\left(H^{\prime}\right)$ \\
\hline $1996^{*}$ & 162 & 30.4 & - & 676 & 154.5 & 5.83 \\
\hline $2011 *$ & 65 & 14 & 571 & 662 & 46 & 4.55 \\
\hline $2011 * *$ & 72 & 15.2 & 819 & 997 & 46 & 4.36 \\
\hline
\end{tabular}


multi-stemmed trees and the latter consisting exclusively of single-stemmed trees. Sprouters and seeders were categorized at the species level while single-stemmed and multi-stemmed trees were categorized at the level of the individual tree and not by species.

\section{Definition of sprouting ability, importance value and ordination of species}

We defined sprouting ability of a species as the proportion of multi-stemmed individuals in the total number of conspecific individuals.

The importance value (IV) of each species was expressed as a percentage and calculated as follows (Curtis and McIntosh 1951):

$$
\begin{aligned}
& I V=\text { (relative basal area }[\mathrm{BA}] \text { of a species + relative } \\
& \text { density of the same species) } / 2 \text { Eq.(1), }
\end{aligned}
$$

where:

Relative $\mathrm{BA}=(\mathrm{BA}$ of a species $/ \mathrm{BA}$ of all species $) \times$ 100

Relative density $=$ (density of a species $/$ density of all species) $\times 100$

Temporal changes of importance values of each species of a community during a successive period could be expressed by a vector with two parameters gradient (Gi) and length $(\mathrm{Li})$ in two-dimensional Cartesian space in which the importance values were plotted (Fig. 2). These parameters were calculated as follows:

$$
\begin{array}{ll}
G i=\arctan \left(I V_{2} / I V_{1}\right) \times 180 / \pi & \text { Eq. (4) } \\
L i=\sqrt{ }\left(I V_{1}^{2}+I V_{2}^{2}\right) & \text { Eq. (5), }
\end{array}
$$

where $I V_{1}$ and $I V_{2}$ are the $I V$ values of a species during the first and most recent observations, respectively. Hereby, species of $G i=0,0<G i<90$ and 90 degrees correspond to disappeared, survived and newcomer

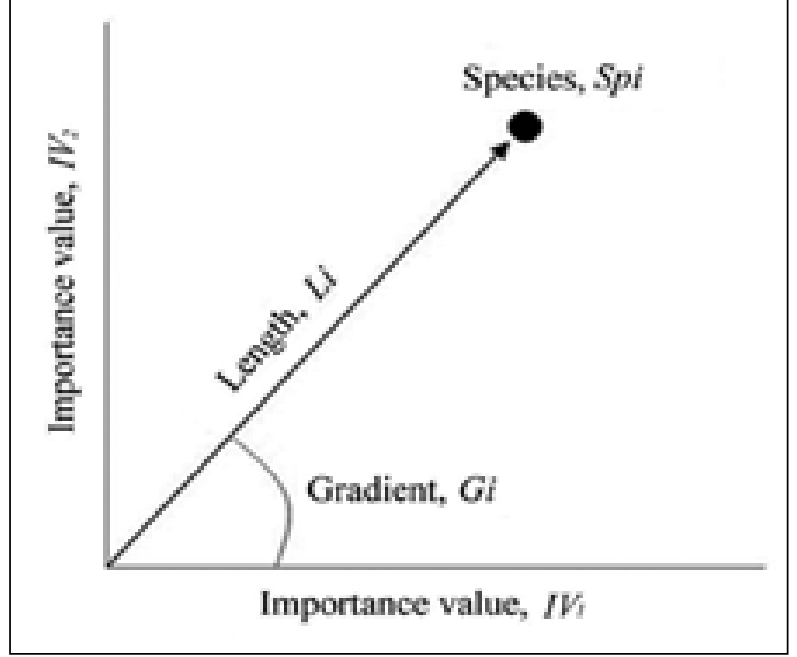

Fig. 2. Definitions of vectors for each species (Spi) showing temporal changes in importance values in the period between the initial time $\left(t_{1}\right)$ and time $\left(t_{2}\right)$ of most recent observations. Symbols $I V_{1}$ and $I V_{2}$ are importance values at times $t_{1}$ and $t_{2}$, respectively. Symbols $G i$ and $L i$ are the gradient and length of the vector Spi, respectively.

species, respectively. A parameter of $L i$ denotes a composition of the importance values of each species at two successional stands being $I V_{1}=L i \times \cos (G i)$ and $I V_{2}=$ $L i \times \sin (G i)$. Thanks to these two parameters, we could understand dynamic changes of all species of a community through a diagram on coordinates of $G i$ and $L i$ (refer to Fig. 5).

\section{RESULTS}

\section{Dynamics of stand structure Dimensional structure}

The species number of trees $\geqq 8 \mathrm{~cm} \mathrm{DBH}$ after logging decreased from 162 to 65 species, with an accompanying decrease in species diversity (Shannon-Wiener's Index) from 5.83 to 4.55 . The average BA of the stand 14 years after logging was nearly half of the original value in the

\begin{tabular}{|c|c|c|c|c|}
\hline \multirow{2}{*}{ Species group } & \multicolumn{2}{|c|}{ Survived species } & \multirow{2}{*}{$\begin{array}{c}\text { Newcomer species } \\
\text { Newcomer }\end{array}$} & \multirow{2}{*}{$\begin{array}{l}\text { Total (single-stemmed } \\
\text { multi-stemmed) }\end{array}$} \\
\hline & Newly regenerated & Non-logged & & \\
\hline Seeders & $2 \%(2,0)$ & $4 \%(4,0)$ & $15 \%(15,0)$ & $21 \%(21,0)$ \\
\hline Sprouters & $47 \%(36,11)$ & $8 \%(5,3)$ & $23 \%(17,6)$ & $79 \%(59,20)$ \\
\hline Total (single-stemmed, multi-stemmed) & $49 \%(38,11)$ & $12 \%(9,3)$ & $38 \%(32,6)$ & $100 \%(80,20)$ \\
\hline
\end{tabular}
mature stand. The density of shoots $\geqq 8 \mathrm{~cm} \mathrm{DBH}$ in 2011 was nearly same as the original value in 1996, and the

Table 2. Importance values $(I V)$ of species groups in 2011. Values in parentheses are $I V$ values of single-stemmed and multi-stemmed trees. 


\section{in 2011 (after logging)}
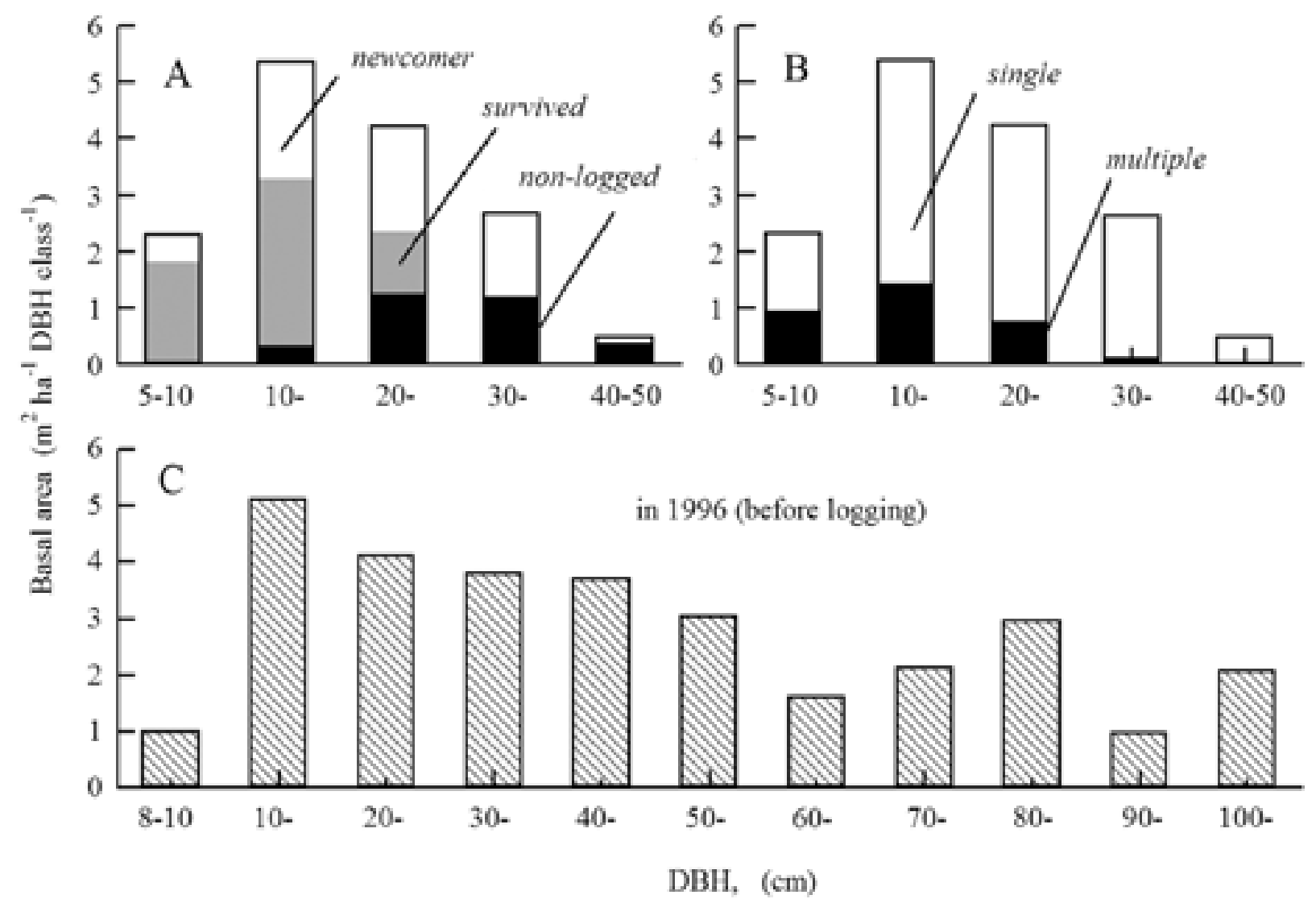

Fig. 3. Basal area distribution of DBH after (A and B) and before (C) logging. The panel A compares species groups (survived and newcomer); non-logged trees belong to the category of survived. Panel B represents proportions of single-stemmed (single) and multi-stemmed (multiple) trees regardless species groups. Panel C is a pattern before logging in 1996.

total density of stems $\geqq 5 \mathrm{~cm}$ was 1.5 times the value of stems $\geqq 8 \mathrm{~cm}$ due to the high density of small shoots in the 5-8 cm DBH category (Table 1). Survived species in the former vegetation accounted for $61 \%$ of the total $I V$ value; non-logged trees made up $12 \%$ of the total. Sprouters were dominant with an $I V$ value of $79 \%$ (Table $2)$. The sprouter category comprised both singlestemmed and multi-stemmed trees. Most of the high $I V$ values for sprouters were attributable to the dominance of single-stemmed trees.

Figure 3 depicts the changes in BA distribution patterns of DBH category between 1996 and 2011. Nonlogged trees accounted for $21 \%$ of total BA and were a major component among larger tree sizes $(\geqq 30 \mathrm{~cm}$ in $\mathrm{DBH})$. Maximum tree size was $46 \mathrm{~cm} \mathrm{DBH}$ for a nonlogged tree of Trema angustifolia. Newcomer tree species had higher representation in larger size classes than new recruits of survived tree species. Pooled across all species, single-stemmed trees accounted for $77 \%$ of the total BA. Their dominance increased with increasing tree size (Fig. 3B).

\section{Horizontal distribution}

Fig. 4 describes the spatial and topographical distribution of BA in 2011. When we compared BA between upper and lower slopes with border value of $28 \mathrm{~m}$ in relative altitude except the projecting 8 subplots, abundance of subplots with higher BA than the average was higher, $53 \%$ on lower slopes and $35 \%$ on higher slopes. These higher BA values were produced by frequently occurring singlestemmed trees. Single-stemmed trees of Macaranga tricocarpa (with the highest rank in $I V$ among newcomer species) tended to occur on lower slopes, mainly. Multistemmed trees of Litsea cubeba with the highest sprouting ability tended to occur on ridge sites around their habitat before logging. 


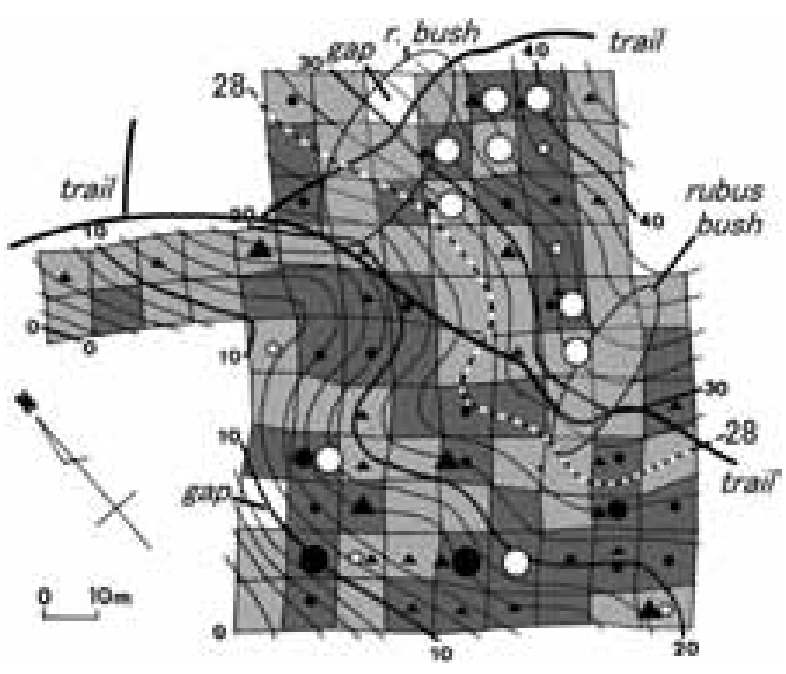

Fig. 4. Horizontal distribution patterns of the present basal area after logging in Gajabuih plot. A small quadrat is a subplot with area of ca. $100 \mathrm{~m}^{2}$ (topographical map from Ogino et al. 1984). Figures on the contour lines show relative altitude (m) being difference from the lowest point. Dark and light gray cells show subplots with higher and lower basal areas than the average value of Gajabuih plot, respectively. Open circles show the habitat of Litsea cubeba, large ones being multistemmed and small ones being single-stemmed. Closed circles and their sizes indicate habitat and tree density of Macaranga tricocarpa, singlestemmed trees, where larger circles indicate higher tree density. Closed triangles and their sizes indicate habitat and tree density of single-stemmed Villebrunea rubescens without multi-stemmed individuals, where larger triangles indicate higher tree density.

\section{Dynamics of species composition \\ Changes in species composition through logging}

Fig. 5B shows the changes in species composition of the Gajabuih plot in the time period between 1996 (before logging) and 2011 (a young regenerating stand); for each species, both $G i$ and $L i$ are indicated. Dynamics of the three species groups could be summarized by the following contents:

- Disappeared species group with $G i=0^{\circ}$ : There were 131 species including several high $I V$ ranked species at the former vegetation such as Deplanchea bancana (third ranking), Nephelium sp. (seventh), Canarium sp. (eighth), Quercus oidocarpa (nineth) and Hopea dryobalanoides (tenth);

- Survived species group with $0<G i<90^{\circ}$ : In this group, there were 31 species, and among those with high $I V$ in the former vegetation, there was a tendency toward decreased dominance (slopes under $45^{\circ}$ ). A few individuals of Shorea maxwelliana and Swintonia schwenkii remained as non-logged trees and a few of Cleistanthus glandulousus remained as new rehabilitators. A small number of species in the current vegetation maintained the dominance that they had before logging $\left(30<G i<60^{\circ}\right)$. Survived sprouters such as Litsea cubeba and Dysoxylum sp. had relatively stable dynamics. Species with high $G i$ were predominant during stand initiation. Villebrunea rubescens, Mallotus paniculatus, Macaranga triloba, Gonystilus forbseii, and Dendrocnide stimulans had higher ranks than before in the current vegetation viz. first, second, fifth, sixth and eighth, respectively (Appendix 1); they were survived sprouters in the recovering stand.

- Newcomer species with $G i=90^{\circ}$ : Vigorous species achieved high ranks regardless of whether they were seeders or sprouters. For example, Macaranga tricocarpa, Omalanthus populneus and Dehaasia sp. were seeders ranking third, twelfth and nineteenth, respectively, in the current vegetation. Sprouters such as Saurauia tristyla, Macaranga javanica, and Macaranga tanaria ranked fourth, seventh and eleventh, respectively.

\section{Sprouting ability of rehabilitators}

There were 37 sprouter species among which sprouting ability varied greatly (Appendix 1). Among dominants, $L$. cubeba had the highest ability (56\%) followed by $V$. rubescens (32\%) and Saurauria tristyla (22\%). Mal. paniculatus, Mac. javanica, G. forbesii and Dysoxylum sp. had sprouting abilities of $<10 \%$. Sprouting ability was examined in relation to maximum $\mathrm{DBH}$ of each species (excluding non-logged trees) and average value of stem hardness.

Twenty six species with data of stem hardness represented by more than two individuals were used for this analysis. Maximum DBH and stem hardness were independent $(P=0.612)$. Multiple regression analysis with a linear model $\left(R^{2}=0.524, F_{2.23}=12.68, P<0.001\right)$ showed that sprouting ability was negatively correlated with maximum DBH $(P=0.0007)$ and positively correlated with average stem hardness $(P=0.012)$. The regression equation was shown by:

sprouting ability $=-2.76 \times$ maximum $\mathrm{DBH}+1.36 \times$ stem hardness $+38.50\left[\%, \mathrm{~cm}, \mathrm{~kg} \mathrm{f} \mathrm{cm}^{-1}\right] \quad$ Eq.(6).

Maximum DBH formed after logging may be considered as potential growth rate. Thus, sprouting ability tended to be negatively correlated with potential stem growth rate. 

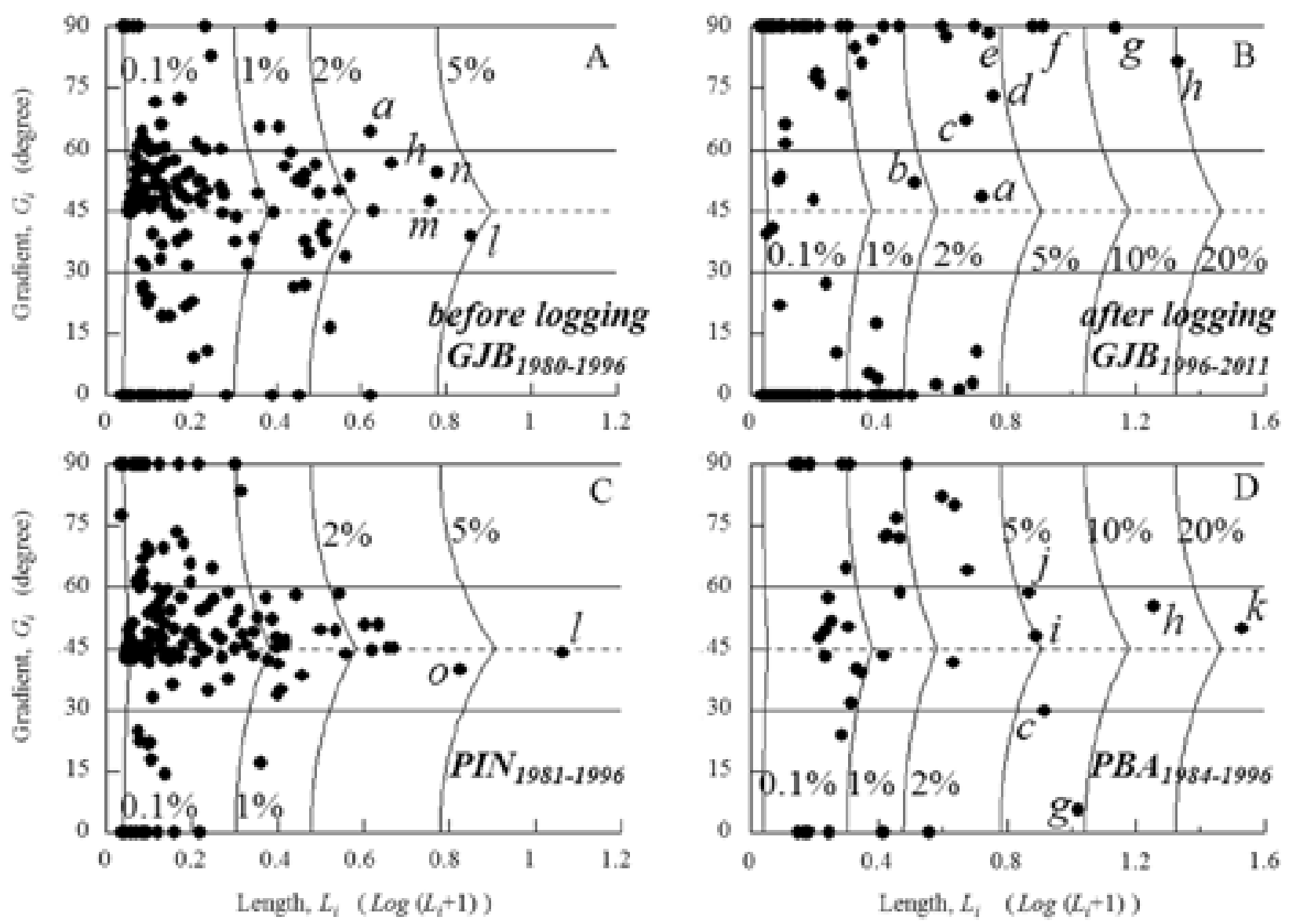

Fig. 5. Ordination of the temporal dynamics of species with two parameters, $G i$ and $L i$, in two mature forests (A and C) and two regenerating forests after clear logging (B and D). A and B are a GJB stand before and after logging, and C and $\mathrm{D}$ are a 1-ha mature forest stand (PIN) and its neighboring secondary forest stand (PBA). Period of observation at each stand is indicated by calendar years as subscript letters of each plot name. Curves in each panel indicate isoclines of importance values (\%). Lowercase single italic letters refer to species' names (see Appendix except $j=$ Elaeocarpus $\mathrm{sp}$.).

The positive correlation of sprouting with stem hardness reflects the relationship between sprouting ability and mechanical strength of the tree trunk.

A storm struck the plot in July 2010, and many dead shoots were found after the event. Estimated mortality was $6.5 \%$ for single-stemmed trees and $0.4 \%$ for multistemmed trees. Average mortality of 10 major species consisting of 707 shoots was negatively correlated with sprouting ability (Fig. 6). Three pioneer species (Omalanthus populneus, Macaranga javanica and Mallous paniculatus) with low sprouting abilities being less than $5 \%$ showed high mortality over $20 \%$ per year. Three other species with sprouting abilities over 20\% (Saurauia tristyla, Villebrunea rubescens and Litsea cubeba) clearly exhibited lower mortality rates. Thus, species with high sprouting ability had enhanced tolerance of storm-force winds, although we did not directly confirm that deaths were caused by the storm.

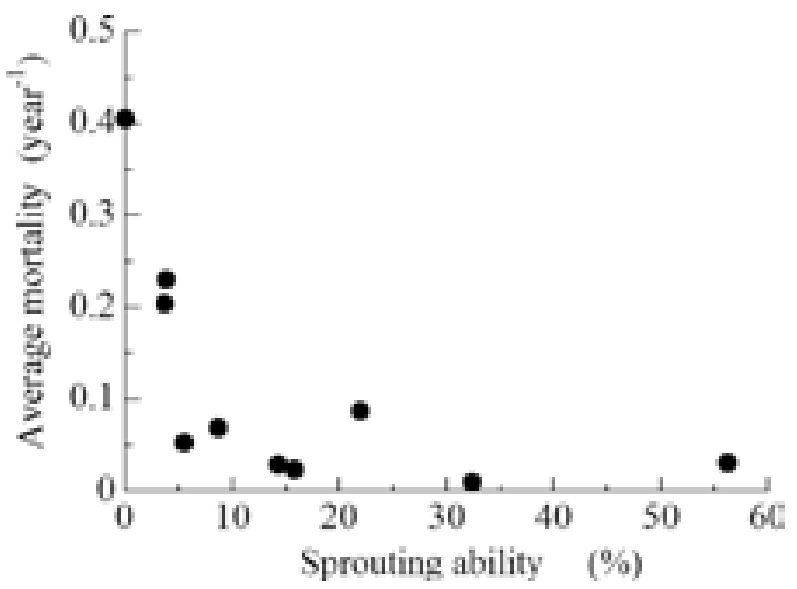

Fig. 6. Relationship between sprouting ability and average mortality of 10 major species in the regenerating Gajabuih plot. 


\section{Regeneration of Villebrunea rubescens}

This species had the highest $I V$ in the current vegetation due to its high tree density and high BA, which matched the values for Mal. paniculatus (second $I V$ ranking) and Mac. tricocarpa (third) (Fig. 7). Regeneration was enhanced by many small single-stemmed and multistemmed trees (Fig. 7B). The average individual BA of multi-stemmed Villebrunea rubescens was $28 \%$ of the value for L. cubeba; for single-stemmed trees, the value of $V$. rubescens was $9 \%$ of that for Mac. tricocarpa. V. rubescens was present in $22 \%$ of subplots in 1996 before logging and in $73 \%$ after logging (100 subplots in total). Eight subplots had gains in BA arising from ingrowth and recruited stems. Fourteen subplots with decreased BA had been subjected to recent logging by neighbouring villagers for local use (presumably for fencing). The other 51 subplots were occupied by newly recruited trees. We compared the BAs of subplots except $V$. rubescens in 1996 between habitat (subplot) of this species and non-habitat in 1996 and 2011, respectively. No significant difference could be detected in these respective years $(P>0.05)$. Hence, the former and current distribution patterns of this species were random and there was no influence of BA of species other than $V$.rubescens in 1996. We examined the present

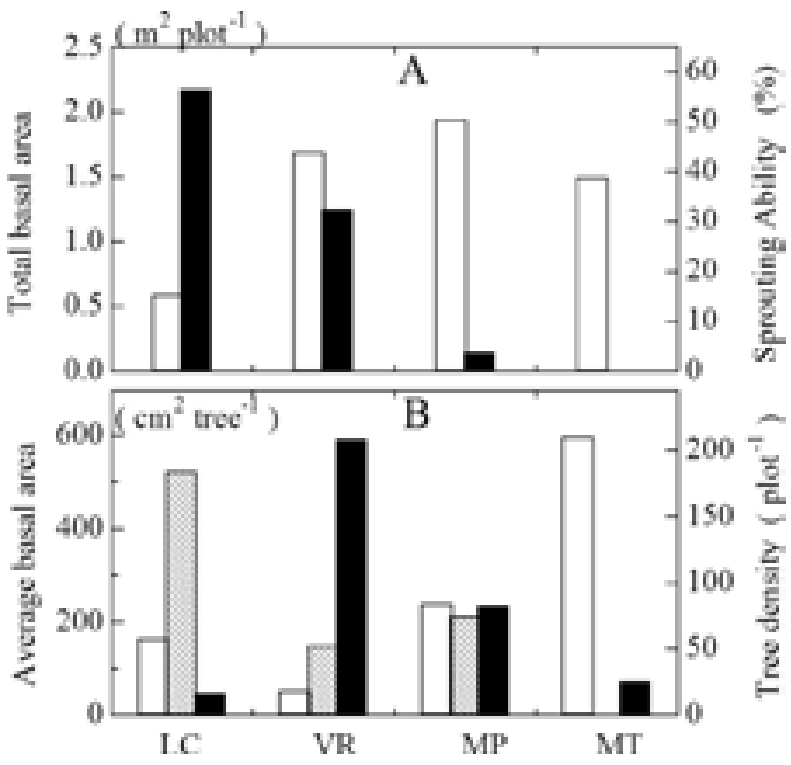

Fig. 7. Basal areas, sprouting ability, and densities of four major species in the regenerating Gajabuih plot. (A) Total basal area (open bars) and sprouting ability (closed bars). (B) Average basal areas of individuals (open and hatched bars) and tree densities (closed bars). LC: Litsea cubeba, VR: Villebrunea rubescens, MP: Mallotus paniculatus, MT: Macaranga tricocarpa. Open and hatched bars are single-stemmed (single) and multi-stemmed (multiple) trees, respectively.
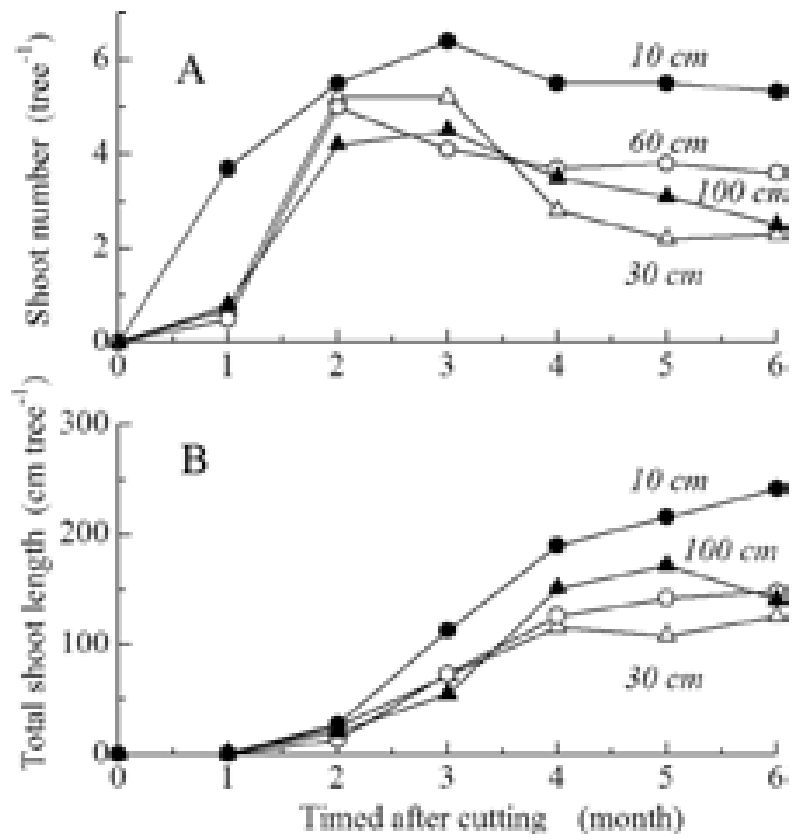

Fig. 8. Growth curves of shoot number (A) and total shoot length (B) of an individual tree after cutting of a stem of Villebrunea rubescens (Clipping Experiment). Figures in each panel are clipped stump heights.

habitat subplots occupied exclusively by either singlestemmed or multi-stemmed trees of $V$. rubescens. Multistemmed trees in the regenerating stand occurred in 14 subplots with no clear site preference. Single-stemmed trees occupied 31 subplots, and tended to have higher tree density in low-elevation sites (Fig. 4).

Villebrunea rubescens responded rapidly to cutting. Buds and shoots started to appear just 1 month afterward (Fig. 8). We found no dead trees 6 months after cutting. Although average shoot production per tree tended to be highest in the $10 \mathrm{~cm}$ clipping category, there were no significant differences among the four categories of cutting height at each observation time $(P>0.05)$; there were also no significant differences among categories in shoot length growth rates. Six months after cutting, average total shoot lengths per stump were 241, 125, 148 and $140 \mathrm{~cm}$ in the respective cutting categories.

\section{DISCUSSION}

\section{Regeneration processes in a tropical rainforest after clear-cutting}

\section{Recovery rates}

Trees in the Gajabuih plot recovered BA at a rate of $15 \mathrm{~m}^{2}$ $\mathrm{ha}^{-1}$ over 14 years post-logging. These rates were lower 
than those in the Pinang Pinang Bawah plot (PBA). Topography greatly affects initial growth rates at PBA and its neighboring secondary forest stand, Pinang Pinang Atas (PAT: Fig. 1; Yoneda et al. 1999) by introducing variation in soil fertility (Kubota et al. 1998). However, GJB and PBA are both located on upper slopes, suggesting that continual disturbance by local people (Photo A) may be a major factor explaining the differences in plot recovery rates, although we cannot rule out soil condition differences as a contributory influence without more direct evidence.

\section{Stand structure before logging}

The regeneration process in GJB was strongly affected by survived tree species in the former vegetation, which accounted for $61 \%$ of $I V$ and $39 \%$ of species number in the current vegetation; however, major climax species of canopy trees would not have been present in the current forest without the existence of a few non-logged tree species. GJB experienced dynamic changes in species composition during the 17 years before logging (Fig. 5A), although stable floristic structure was maintained in the Pinang Pinang plot (PIN) as shown in Fig. 5C. Some climax species with high $I V$ disappeared during the prelogging period at GJB, and the $I V$ values of some secondary forest species such as $V$. rubescens and $L$. cubeba increased. The regenerating stand at PBA also had highest $I V(68 \%)$ among species common to the prelogged GJB vegetation, in contrast to another (56\%; PIN) neighboring mature forest stand (Table 3). Thus, many secondary species, including common taxa, were able to recover in the former GJB (before logging in 1997) after storm damage (Yoneda et al. 1998), but it is not clear whether these survived rehabilitators originated from juvenile trees or new seedlings after logging.

\section{Life strategies of major rehabilitators}

Sprouting species accounted for $79 \%$ of the total $I V$, and the proportion of survived species was $90 \%$. Sprouting ability tended to have a trade-off relationship with potential growth rate and investment in the maintenance of physical strength. Therefore, sprouting ability may be an important life strategy (Turner 2001, Yoneda et al. 2009). L. cubeba, with the highest sprouting ability (56\%), maintained a high $I V$ value similar to that in the former vegetation (Fig. 5B) through production of small numbers of large individuals with multiple stems (Fig. 7B) in ridge sites (Fig. 4). However, tree density was reduced slightly in the current vegetation. The average BA of multistemmed trees was nearly equivalent to that of a singlestemmed tree of Mac. tricocarpa, which had the highest shoot growth rates (Fig. 7B). These data suggest that the preferred habitat of this species occurs on ridge sites where trees are able to take advantage of small perturbations by increasing sprouting ability. Sprouting ability varies not only among species but also among sites, even for the same species (Nanami et al. 2004). This variation allows a species to persist in a site after a wide range of disturbances (Bellingham and Sparrow 2000, Bond and Midgley 2001, 2003). V. rubescens, whose sprouting ability was $32 \%$, had some shade tolerance, as indicated by its random habitat preferences, which were not related to BAs at a range of sites in the former vegetation; this species regenerated many small saplings. The average size of single-stemmed trees of $V$. rubescens, however, was appreciably smaller than single stemmed trees of Mal. paniculatus, which had a sprouting ability of 4\% (Fig. 7B). Hence, V. rubescens appears to have advantages in sites with reduced light and nutrient levels. Typical pioneer species subjected to disturbance have vigorous regeneration ability at resource-rich sites (Swain and Whitmore 1988, Whitmore 1989). Rapid responses to stem clipping in $V$. rubescens may be associated with fast turnover of aboveground parts supporting photosynthesis, structural stability and belowground resource storage (Chong et al. 2007). Mal. paniculatus was able to occupy habitat in both gap sites in mature stands and in regenerating stands (GJB, PBA, and PAT)

Table 3. Similarities of species composition among four forest stands in West Sumatra (Yoneda et al. 1999). Single bold numbers refer to the number of species common to two stands. Italicized number pairs show the proportion of common species in the importance value. Left and right values in each pair refer to forest stands in the same row and same column, respectively.

\begin{tabular}{ccccc}
\hline Forest stand & GJB 11 & GJB 96 & PIN 96 & PBA 96 \\
\hline GJB 11 & $\mathbf{6 5}$ & $\mathbf{3 1}$ & $\mathbf{2 6}$ & $\mathbf{1 3}$ \\
GJB 96 & $29 \% / 61 \%$ & $\mathbf{1 6 2}$ & $\mathbf{7 7}$ & $\mathbf{2 0}$ \\
PIN 96 & $24 \% / 42 \%$ & $51 \% / 55 \%$ & $\mathbf{2 1 3}$ & $\mathbf{2 3}$ \\
PBA 96 & $61 \% / 54 \%$ & $68 \% / 12 \%$ & $56 \% / 9 \%$ & $\mathbf{4 3}$ \\
\hline
\end{tabular}


in West Sumatra. This species suffered high mortality rates, and reached a maximum size of $<30 \mathrm{~cm} \mathrm{DBH}$. Thus, Mal. paniculatus with its wide dispersal capability (Darrell et al. 1981) is a typical pioneer species with enhanced seedling production in open sites and a short lifespan. Mac. tricocarpa, also a pioneer species, was characterized by high growth rates, reaching $37 \mathrm{~cm} \mathrm{DBH}$ over 14 years; its preferred habitat was on lower slopes (Figs. 4 and 7). Mac. mollucanus had similar traits, growing to $40 \mathrm{~cm}$ DBH over 15 years on lower slopes at PAT, where it experienced a high mortality rate (Yoneda et al. 1999).

\section{Future succession}

Figure 5D shows the changes in species composition during the period between $4^{\text {th }}$ year and $16^{\text {th }}$ year after logging at PBA in 1980 (Yoneda et al. 1999). Taking into account differences in BA growth rates between PBA and the regenerating stand at $G J B$, these years at PBA correspond to 10 years and 19 years at GJB, respectively, in terms of BA. PBA had some markedly dominant species originating from seed germination after logging. There were successive changes from these species to "sprout species" and primary species during the recovery period. The early and later species groups at PBA closely corresponded to newcomer (including Mal. paniculatus) and survived species, respectively, at GJB. We expect changes at GJB over the next several years that will be similar to those at PBA, with some variability in species composition among topographical conditions. However, the sere at GJB is different from that at PBA in the initial stages because of a high dominance of species in common with the former vegetation. A smooth succession to primary species in GJB is perhaps unlikely considering its present isolation among surrounding fields (ladang) and secondary forest.

\section{Sprout regeneration in a tropical rainforest}

We did not find trees sprouted from large logged stumps in GJB, and climax species with multiple stems were few in relation to the many sprouters among survived secondary forest species. Sprouting abilities usually decrease with increasing DBH (Tirmenstein 1991, Weigel and Peng 2002). Yamada et al. (2001) found that the ability to sprout of some canopy trees in tropical peat swamp forest is restricted to their juvenile stage; no production of vegetative sprouts were observed in their reproductive stage. In a neotropical rainforest, Putz and
Brokaw (1989) explained that this character can be due to the lack of resting buds or thick barks that prevent buds from emerging. Furthermore, this negative relationship is probably strong in the tropics because of high energy consumption in a stump-root system with large biomass under high temperatures (Yoda 1978). E. Suzuki (personal comm.) noted that some climax species in a tropical rainforest located in central Kalimantan had high sprouting ability matching those of secondary species through an experiment of stump planting with small sticks. However, climax species tend to have lower growth rates than early successional tree species (Yoneda et al. 2009), which is disadvantageous in competitive interactions with pioneer species, at least during early regeneration stages. This may account for large-scale retrogression of climax species following logging of a mature forest stand.

Sprouting ability in the logged GJB in 2011 was $19 \%$ of tree density, and values tended to be higher on upper slopes with poor resources for growth and higher disturbance. Sprouting abilities were 20\%, 17\% (Thiam unpublished data) and 30\% (Yoneda 2000), respectively, in three secondary forest stands in West Sumatra: PBA (20 $\mathrm{m}^{2} \mathrm{ha}^{-1}$ in BA 16 years after logging), a 1-ha secondary forest stand $\left(25 \mathrm{~m}^{2} \mathrm{ha}^{-1}\right)$ in an experimental forest at Andalas University and a secondary forest stand $\left(22 \mathrm{~m}^{2}\right.$ $\mathrm{ha}^{-1}$, high disturbance) near a village in Sipisang $50 \mathrm{~km}$ northward from GJB, respectively (Yoneda et al. 1999). Thus, the sprouting ability of a secondary forest in this region of Indonesia is ca. $20 \%$, increasing to ca. $30 \%$ with

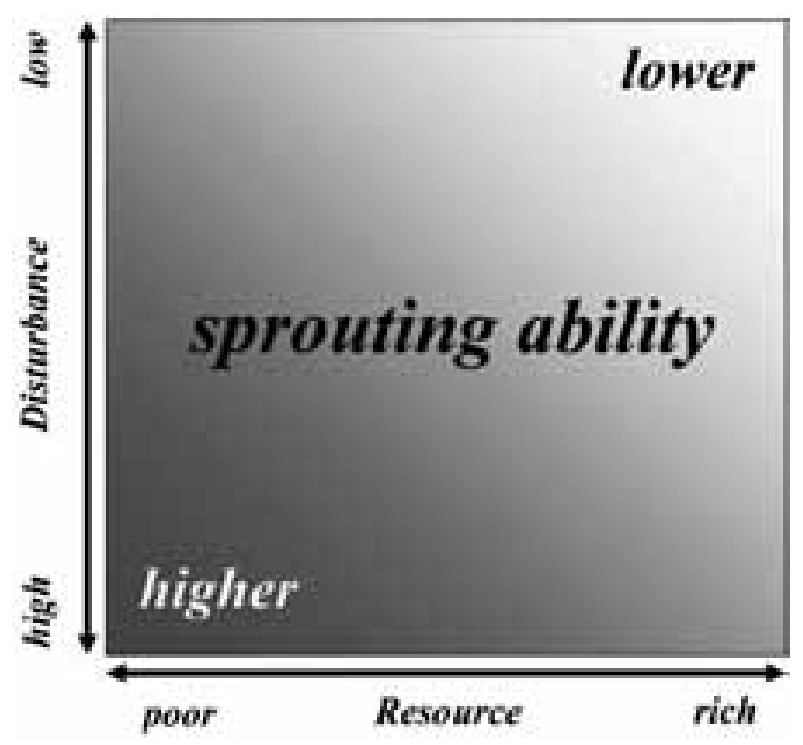

Fig. 9. Schematic of variability in sprouting ability in vegetation across gradients of disturbance and resources. 
strong disturbance. Among diverse regions around the globe, there is enhanced regeneration ability in fire-prone environments such as savanna and grassland (Midgley 1996). Three savanna stands $\left(5.2-7.7 \mathrm{~m}^{2} \mathrm{ha}^{-1}\right.$ in BA) in Southeastern Senegal that are frequently burned have sprouting abilities of 47-53\% (Thiam, unpublished). Everham and Brokaw (1996) measured higher incidences of sprouting species in tropical sites (mean 52\%) than in temperate forests $(36 \%)$. It must be considered that various factors can influence the vegetative regeneration by sprouting known that all species have some sprouting ability (Peter and Westoby 2004). We could consider that resources (light, nutrient, water) and disturbance (logging, storm, fires, animal feeding) would be major external factors influencing sprouting ability (Fig. 9), though it could be closely connected with various internal factors such as tree sizes, age, life form and so on. Such variation probably occurs locally and globally across topographical/latitudinal gradients of resources and human/natural disturbances (Tredici 2001, Pujalon et al. 2008).

ACKNOWLEDGMENTS We express our sincere thanks to Dr. Eizi Suzuki (Kagoshima University) for his valuable support, as well as to the students of Japanese universities and Andalas University. We express our gratitude to the local people in Gadut for their cooperation during the fieldwork. This study was partly supported by the Nippon Life Insurance Foundation in 1995 (T. Yoneda), a Grant-in-Aid (Oversea-B-12575006) from the Japanese Ministry of Education, Science, Sports and Culture during 2000-2003 (T. Yoneda), the Global Environmental Research Fund (E-051), Ministry of the Environment, Japan during 2005-2007 (E. Suzuki), and the Japanese Society for the Promotion of Science (JSPS) through the International Training Program of Kagoshima University during 2007-2012 (E. Suzuki).

\section{REFERENCES}

Bellingham PJ. Sparrow AD. 2000. Resprouting as a life story strategy in woody plant communities. Oikos 89:409-416.

Bond WJ, Midley JJ. 2001. Ecology of sprouting in woody plants: the persistent niche. Trends in Ecology and Evolution 16:4155.

Bond WJ, Midley JJ. 2003. The evolutionary ecology of sprouting in woody plants. International Journal of Plant Sciences 164:103-114.

Chong C, Edwards W, Waycott M. 2007. Differences in resprouting ability are not related to seed size or seedling growth in four riparian woody species. Journal of Ecology 95:840-850.

Connell JH. 1978. Diversity in tropical rain forests and coral reefs. Science 199:1302-1310.

Curtis JT, McIntosh RP. 1951. An upland continuum in the prairie forest border region of Wosconsin. Ecology 32:476-496.

Darrell CW, Herman HS. Daniel BB. 1981. Forest succession: concepts and application. Springer-verlag, NewYork.

Everham III EM, Brokaw NVL. 1996. Forest damage and recovery from catastrophic wind. The Botanical Review 62:113-185.

Hamilton C. 1997. The sustainability of logging in Indonesia's tropical forests: A dynamic input-output analysis. Ecological economics 21:183-195.

Hotta M, Tamin R, Ito M. 1984. The flora of Gunung Gadut area. In: Hotta M. (ed.) Forest ecology and flora of G. Gadut West Sumatra, Sumatra narure study (Botany). Kyoto University, Kyoto. 15-37.

Hotta M. 1989. Diversity and plant-animal interaction in equatorial rainforest: Report of the 1987-1988 Sumatra Research. Sumatra Nature Study (Botany). Kagoshima University.

Kimmins JP. 2004. Forest Ecology. A Fondation for Sustainable Forest Management and Environmental Ethics in Forestry. $3^{\text {rd }}$ ed. The University of British Columbia.

Kobayashi S. 2004. Landscape rehabilitation of degraded tropical forest ecosystems Case study of the CIFOR/Japan project in Indonesia and Peru. Forest Ecology and Management 201:13-22.

Kubota D, Masunaga T, Hotta M, Shinmura Y, Wakatsuki T. 1998. Soil environment and tree species diversity in tropical rain forest, West Sumatra, Indonesia. In: Schulte A, Ruhiyat D (eds.) Soils of tropical forest ecosystems: characteristics, ecology and management. Springer, Berlin. 159-167.

Laumonier Y, Uryu U, Stuwi M, Budiman A, Setiabudi B, Hadian O. 2010. Eco-floristic sectors and deforestation threats in Sumatra: identifying new conservation area network priorities for ecosystem-based land use planning. Biodiversity Conservation 19:1153-1174.

Midgley JJ. 1996. Why the world's vegetation is not totally dominated by sprouting plants; because sprouters are shorter than reseeders. Ecography 19:92-95.

Nanami S, Kawaguchi H, Tateno R, Li C, Katagiri S. 2004. Sprouting traits and population structure of co-occurring Castanopsis species in an evergreen broad-leaved forest in southern China. Ecological Research 19:341-348.

Ng FSP. 1999. The development of the tree trunk in relation to apical dominance and other shoot organizational concepts. Journal of Tropical. Forest Sciences 11:270-285.

Nishimura S, Yoneda T, Fujii S, Mukhtar E, Abe H, Kanzaki M. 2006. Factors influencing the floristic composition of a hill forest in West Sumatra. Tropics 15:165-175.

Ogino K, Hotta M, Tamin R, Yoneda T. 1984. Forest ecology of 
G. Gadut area. In: Hotta M (ed.) Forest ecology and flora of G. Gadut West Sumatra, Sumatra narure Study (Botany). Kyoto University, Kyoto. 15-37.

Otsuka M. 2009. Impacts of farmers' land use on natural forest conversion: a case study from West Sumatra, Indonesia. Tropics 18:155-166.

Peter AV, Westoby M. 2004. Sprouting ability across diverse disturbances and vegetation types worldwide. Journal of Ecology 92:310-320.

Pujalon S, Piola F, Bornette G. 2008. Abiotic stresses increase regeneration ability. Evolution Ecology 22:493-506 .

Putz FP, Brokaw NVL. 1989. Sprouting of broken trees on Barro Colorado Island, Panama. Ecology 70:508-512.

Swain MD, Whitmore TC. 1988. On the definition of ecological species groups in tropical rain forest. Vegetatio 75:81-86.

Thiam E, Yoneda T. Recent degradation processes in a tropical secondary forest in West Sumatra. Tropics (accepted)

Tirmenstein DA. 1991. Acer saccharum. In: Fire Effects Information System, [Online]. U.S. Department of Agriculture, Forest Service, http://www.fs.fed.us/ database/feis

Tredici PD. 2001. Sprouting in temperate trees: a morphological and ecological review. The Botanical Review 67:121-140.

Turner IM. 2001. The ecology of trees in the tropical rain forest. Cambridge Tropical Biology Series, Cambridge University Press, Cambridge.

Vitousek PM, Mooney HA, Lubchenco J, Melillo JM. 1997. Human domination of earth's ecosystems. Science 277:494499.

Weigel DR, Peng C-YJ. 2002. Predicting stump sprouting and competitive success of five oak species in southern Indiana. Canadian Journal of Forest Research . 32:703-712.

Whitmore TC. 1989. Canopy gaps and the two major groups of forest trees. Ecology 70:536-538.

Whitmore TC. 1998. An introduction to tropical rain forests. Second edition. Oxford University Press, Oxford.

Yamada T, Kumagawa Y, Suzuki E. 2001. Adaptive significance of vegetative sprouting for a tropical canopy tree, Scaphium longiflorum (Sterculiaceae), in a peat swamp forest in Central Kalimantan. Ecological Research 16:641647.

Yamamoto SI. 1992. The gap theory in forest dynamics. Botanical Magazine Tokyo 105:375-383.

Yoda K. 1978. Estimation of community respiration. In: Kira T, Ono Y, Hosokawa T (eds.) Biological production in a warm-temperate evergreen oak forest of Japan. JIBP Synthesis 18, University of Tokyo Press, Tokyo. 112-138.

Yoneda T. 1997. Instruction for measurement of hardness of stem wood in the field. Tropical Ecology Lettters 27:17-20. (in Japanese)

Yoneda T. 2000. Vegetational structure of the Minangkabau's village, West Sumatra, Indonesia. Research Report of the Japan Center for Area Studies (JVAS) 3:49-83. (in Japanese with English summary).
Yoneda T, Tamin R, Ogino K. 1990. Dynamics of aboveground big woody organs in a foothill dipterocarp forest, West Sumatra, Indonesia. Ecological Research 5:111-130.

Yoneda T, Ogino K, Kohyama T, Tamin R, Syahbuddin, Rahman M. 1994. Horizontal variance of stand structure and productivity in a tropical foothill rain forest, West Sumatra, Indonesia. Tropics 4:17:33.

Yoneda T, Fujii S, Nishimura S. 1998. Storm impact on an equatorial rain forest in West Sumatra, Indonesia. In: Poonsward P (ed.) The Asian hornbills: ecology and conservation. Thai Studies in Biodiversity, 191-201.

Yoneda T, Kohyama T, Hotta M. 1999. Successive changes of structure and productivity of tropical Secondary forest stands after clear cutting in West Sumatra, Indonesia. Tropics 8:357-375.

Yoneda T, Mizunaga H, Nishimura S, Fujii S, Tamin R. 2006. Stand structure and dynamics of a tropical secondary forest: a rural forest in West Sumatra, Indonesia. Tropics 15:189-199.

Yoneda T, Nishimura S, Fujii S, Mukhtar E. 2009. Tree guild composition of a hill dipterocarp forest in West Sumatra, Indonesia. Tropics 18:143-154.

Received 25 June 2012

Accepted 4 Oct. 2012 
Appendix 1. Importance values $I V$, vectors $L_{i}$ and $G_{i}$, and sprouting abilities of dominant taxa in each species group at GJB.

\begin{tabular}{|c|c|c|c|c|c|c|c|c|}
\hline \multicolumn{2}{|c|}{ Species category } & Species name (Family) & Ref. Fig. 5 & $I V(\%)$ & $\begin{array}{c}\text { Rank } \\
1996 / 2011 \\
\end{array}$ & $\mathrm{Li}(\%)$ & $G i\left(^{\circ}\right)$ & $\begin{array}{l}\text { Sprouting } \\
\text { ability }(\%)\end{array}$ \\
\hline \multirow{21}{*}{ Survived species } & \multirow{10}{*}{ Seeders } & Trema angustifolia (Ulm.) & & 3.07 & $103 / 10$ & 3.08 & 87.58 & 0.00 \\
\hline & & Vernonia arborea (Ast.) & $k$ & 1.42 & $-/ 15$ & 1.42 & 86.78 & 0.00 \\
\hline & & Shorea maxwelliana (Dip.) & $n$ & 0.78 & $1 / 22$ & 4.09 & 10.48 & 0.00 \\
\hline & & Eugenia sp. (Myr.) & & 0.44 & $23 / 32$ & 1.48 & 17.44 & 0.00 \\
\hline & & Aporosa antennifera (Phy.) & & 0.33 & $146 / 36$ & 0.73 & 27.22 & 0.00 \\
\hline & & Artocarpus glauca. (Mor.) & & 0.27 & $111 / 39$ & 0.29 & 66.05 & 0.00 \\
\hline & & Cryptocarya nitens. (Lau.) & & 0.27 & $77 / 40$ & 0.30 & 61.43 & 0.00 \\
\hline & & Knema horspelum (Myr.) & & 0.20 & $114 / 43$ & 0.25 & 53.21 & 0.00 \\
\hline & & Swintonia schwenkii (Ana.) & $l$ & 0.19 & $2 / 44$ & 3.94 & 2.89 & 0.00 \\
\hline & & Durio griffithii (Bom.) & & 0.15 & $27 / 53$ & 0.87 & 10.08 & 0.00 \\
\hline & \multirow{11}{*}{ Sprouters } & Villebrunea rubescens (Urt.) & $h$ & 20.23 & $4 / 1$ & 20.45 & 81.50 & 32.38 \\
\hline & & Mallotus paniculatus (Eup.) & $g$ & 12.73 & $161 / 2$ & 12.73 & 89.59 & 3.70 \\
\hline & & Macaranga triloba (Eup.) & $e$ & 4.54 & $122 / 5$ & 4.54 & 88.23 & 14.28 \\
\hline & & Gonystylus forbesii (Thy.) & $d$ & 4.50 & $20 / 6$ & 4.70 & 73.08 & 5.55 \\
\hline & & Dendrocnide stimulans (Urti.) & $c$ & 3.44 & $16 / 8$ & 3.73 & 67.14 & 15.78 \\
\hline & & Litsea Cubeba (Lau.) & $a$ & 3.20 & $5 / 9$ & 4.27 & 48.41 & 56.25 \\
\hline & & Dysoxylum sp. (Mel.) & $b$ & 1.77 & $52 / 13$ & 2.26 & 51.80 & 7.69 \\
\hline & & Sterculia cordata (Ste.) & & 1.21 & $89 / 16$ & 1.23 & 81.12 & 22.20 \\
\hline & & Ficus pubinervis. (Mor.) & & 1.13 & $142 / 17$ & 1.13 & 84.94 & 14.28 \\
\hline & & Diospyros symchuanensis (Ebe.) & & 0.90 & $80 / 21$ & 0.94 & 73.39 & 7.69 \\
\hline & & Phyllanthusindicus (Eup) & & 0.64 & $105 / 25$ & 0.66 & 76.06 & 12.50 \\
\hline \multirow{21}{*}{ Newcomer species } & \multirow{10}{*}{ Seeders } & Macaranga tricocarpa (Eup.) & $f$ & 7.20 & $0 / 3$ & 7.20 & 90.00 & 0.00 \\
\hline & & Omalanthus populneus (Eup.) & & 1.93 & $0 / 12$ & 1.93 & 90.00 & 0.00 \\
\hline & & Dehaasia sp. (Lau.) & & 1.00 & $0 / 19$ & 1.00 & 90.00 & 0.00 \\
\hline & & Coffea robusta (Rub.) & & 0.92 & $0 / 20$ & 0.92 & 90.00 & 0.00 \\
\hline & & Saurauia reinwarthiana (Sau.) & & 0.49 & $0 / 29$ & 0.49 & 90.00 & 0.00 \\
\hline & & Duranta sp. (Ver.) & & 0.47 & $0 / 31$ & 0.47 & 90.00 & 0.00 \\
\hline & & Ficus vulva (Mor.) & & 0.43 & $0 / 33$ & 0.43 & 90.00 & 0.00 \\
\hline & & Endospermum moluccanum (Eup.) & & 0.36 & $0 / 35$ & 0.36 & 90.00 & 0.00 \\
\hline & & Ixonanthes sp. (Ixo.) & & 0.27 & $0 / 37$ & 0.27 & 90.00 & 0.00 \\
\hline & & Glochidion rubrum (Eup.) & & 0.16 & $0 / 50$ & 0.16 & 90.00 & 0.00 \\
\hline & \multirow{11}{*}{ Sprouters } & Saurauia tristyla (Sau.) & & 6.61 & $0 / 4$ & 6.61 & 90.00 & 22.00 \\
\hline & & Macaranga javanica (Eup.) & & 4.02 & $0 / 7$ & 4.02 & 90.00 & 3.84 \\
\hline & & Macaranga tanaria (Eup.) & & 2.96 & $0 / 11$ & 2.96 & 90.00 & 8.69 \\
\hline & & Dichapetalum sp (Dic.) & & 1.03 & $0 / 18$ & 1.03 & 90.00 & 14.28 \\
\hline & & Melicope sp. (Rut.) & & 0.65 & $0 / 23$ & 0.65 & 90.00 & 50.00 \\
\hline & & Sauropus sp. (Phy.) & & 0.64 & $0 / 24$ & 0.64 & 90.00 & 25.00 \\
\hline & & Syzygium sp. (Myr.) & & 0.53 & $0 / 28$ & 0.53 & 90.00 & 25.00 \\
\hline & & Saurauia reinwarthiana (Sau.) & & 0.49 & $0 / 29$ & 0.49 & 90.00 & 0.00 \\
\hline & & Payena acuminata (Sap.) & & 0.49 & $0 / 30$ & 0.49 & 90.00 & 25.00 \\
\hline & & Alangium rotudifolium (Ala.) & & 0.28 & $0 / 38$ & 0.28 & 90.00 & 33.33 \\
\hline & & Litsea noronhae (Lau.) & & 0.21 & $0 / 42$ & 0.21 & 90.00 & 100.00 \\
\hline \multirow{10}{*}{\multicolumn{2}{|c|}{ Disappeared species }} & Deplanchea bancana (Big.) & $m$ & 3.51 & $3 / 0$ & 4.62 & 0.00 & - \\
\hline & & Nephelium sp. (Sap.) & & 2.22 & $7 / 0$ & 7.34 & 0.00 & - \\
\hline & & Canarium sp. (Bur.) & & 1.94 & $8 / 0$ & 8.23 & 0.00 & - \\
\hline & & Quercus oidocarpa (Fag.) & & 1.76 & $9 / 0$ & 9.17 & 0.00 & - \\
\hline & & Shorea sumatrana (Dip.) & & 1.66 & $10 / 0$ & 10.14 & 0.00 & - \\
\hline & & Hopea dryobalanoides (Dip.) & & 1.58 & $11 / 0$ & 11.11 & 0.00 & - \\
\hline & & Phoebe grandis (Lau.) & & 1.52 & $12 / 0$ & 12.10 & 0.00 & - \\
\hline & & $\begin{array}{l}\text { Pithecellobium microcarpium } \\
\text { (Leg.) }\end{array}$ & & 1.48 & $14 / 0$ & 14.08 & 0.00 & - \\
\hline & & Anisophyllea sp. (Rhi.) & & 1.45 & $16 / 0$ & 16.07 & 0.00 & - \\
\hline & & Styrax paralleloneurum (Sty.) & $i$ & 1.45 & $17 / 0$ & 17.06 & 0.00 & - \\
\hline
\end{tabular}


